\title{
Nota sobre Piolin e o modernismo paulista *
}

\author{
Sérgio de Carvalho
}

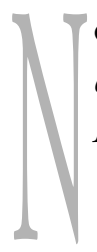

o primeiro número da revista Terra roxa e outras terras, em janeiro de 1926, escreve Antonio de Alcântara Machado:

"São Paulo tem visto companhias nacionais de toda a sorte. Incontáveis. De todas elas, a única, bem nacional, bem mesmo, é a de Piolin! Ali no Circo Alcebíades! Palavra. Piolin, sim, é brasileiro. Representa Dioguinho, o Tenente Galinha, Piolin sócio do Diabo, e outras cousas assim, que ele chama de pantomimas, deliciosamente ingênuas, estupendas, brasileiras até ali.” (Machado, 1926, p. 2)

Vistos em conjunto, algo de facilitador parece haver nos elogios modernistas ao palhaço Piolin. Aquilo que Roberto Schwarz apontou num poema de Oswald de Andrade - uma "plenitude moderna (e idealizada) das sensaçôes, sem pecado, superstição ou conflito, o gosto de ver e ser visto, tão característico da inocência cultivada" (Schwarz, 1989, p. 23) -, elementos que vêm na crista da prosperidade do café, parecem ressoar nesta eleição.

Creio que, em boa parte, o programa primitivista da vanguarda paulista procurou resol- ver o impasse da representação brasileira pela mitificação da liberdade comunitária pré-burguesa.

É certo que isso contém muito de anulação de antagonismos sociais e, menos do que uma resolução concreta de um problema que na verdade está também fora da arte - o da representação de uma sociabilidade sem indivíduos -, propõe um apaziguamento provisório pela suspensão festiva, cuja verdade depende de uma atitude artística que circunscreve a obra. Por outro lado, esse deslocamento no sentido de uma perspectiva de fato coletivizadora já é um avanço no pensamento teatral de Alcântara Machado.

E nisso ele esteve de acordo com Oswald de Andrade e com Mário de Andrade, que desenvolveu o elogio a Piolin no segundo número da Terra roxa, sob o pseudônimo de Pau D’Alho: "Os únicos espetáculos teatrais que a gente
inda pode freqüentar no Brasil são o circo e a
revista. Só nestes inda tem criação. Não é que
os poetas autores de tais revistas e pantomi-
mas saibam o que é criação ou conservem al-
guma tradição efetivamente nacional, porém
as próprias circunstâncias da liberdade sem

Sérgio de Carvalho é dramaturgo e encenador; dooutorando pelo Departamento de Literatura Brasileira da FFLCH-USP.

* Este texto integrou o relatório de qualificação para doutoramento na área de Literatura Brasileira apresentado pelo autor ao Departamento de Letras Clássicas e Vernáculas da FFLCH -USP, sob orientação de José Antonio Pasta Jr. 
restrições e da vagueza desses gêneros dramáticos permite aos criadores deles as maiores extravagâncias. Criam por isso sem leis nem tradiçōes importadas, criam movidos pelas necessidades artísticas do momento e do gênero, pelo interesse de agradar e pelas determinações inconscientes da própria personalidade." (Andrade, 1926, p. 2.)

Merece destaque o elogio à dimensão subjetiva de uma criação artística como essa: acima da conservação de alguma tradição efetivamente nacional está a autonomia do artista conquistada pelas "circunstâncias de liberdade sem restrições e da vagueza." Piolin parecia trabalhar com meios tão rarefeitos e cambiantes quanto seus objetos sugeriam. Por outro lado, a aparência de coisa "informe" era sustentada por uma precisão técnica do ridículo, que segundo Mário de Andrade, salvaria da "perdição" esse gênero de pantomimas. No entanto, ao que parece, o olhar modernista sobre Piolin encantava-se menos com a base da técnica física e imaginária, do que com o livre acesso ao inconsciente expresso naquelas entradas cômicas. Importava seu jeito de "criação verdadeira", provinda de regiôes em que a intencionalidade construtiva não chega.

Com a vantagem de sua força cênica ser reconhecível de imediato por qualquer platéia, os princípios cômicos dos números circenses de Piolin continham a mesma rapidez, poder de síntese e a "fulminância" que Alcântara Machado emprestava do cinema e dos jornais para seus contos.

As formas cênicas de Piolin tinham algo de uma irrealização absoluta, que encantava os modernistas por seu duplo sentido de incompletude e descompromisso com a representação exterior da realidade segundo hábitos da verossimilhança. Foi com Piolin que Alcântara Machado reconheceu virtudes na desordem, ainda que não tivesse procurado relacionar a aparente informalidade com procedimentos de construção que todo bom palhaço exercita até incorporá-los como seus. Piolin era sobretudo um símbolo de ingenuidade e de bagunça feliz. Parecia resolver muitas contradiçóes estéticas e, segundo padrões dados pela própria vanguarda européia, representava o sonho de que, da nossa confusão, poderia sair matéria para a transformação. Alcântara Machado escreve em 1928:

"Um teatro bagunça da bagunça sairá. [...] Enquanto isso o teatro europeu busca o que já possuímos: ora o que ele (teatro europeu) procura é o informe que nós somos. Não saímos até hoje do princípio. E o princípio é a farsa popular, anônima, grosseira. É a desordem das cançôes, bailados, diálogos e cenas de fundo lírico, anedótico ou religioso. Coisa que entre nós se encontra no circo, nos terreiros, nos adores, nas ruas, nas macumbas." (Machado, 1928, apud Lara, 1987, p. 115).

O fato é que a conversão de Alcântara Machado a gêneros como a farsa e a comédia de costumes, que antes abominava, deriva de uma autorização dada pelo "programa primitivista" das vanguardas européias em sua vontade de romper o dogmatismo da tradição estética em favor de acesso mais profundo à realidade. Nesta "salvação pelo popular" - segundo ele, a única coisa que ainda se podia tentar no teatro brasileiro -, o ponto de referência continuava fora do país, ainda que a intenção fosse outra. E a proposta de recuo em direção a uma subjetividade livre, vislumbre modernista de uma possibilidade brasileira de "sujeito humanista burguês", era a defesa de um salvo-conduto ao artista antes de ser uma proposta de prática concreta para as obras.

Por outro lado, aquela "desenvoltura do sujeito" conquistada pela nudez do fato (uso de novo termos de Roberto Schwarz) pode ser lida, em suas contradições, como um primeiro passo para uma práxis, e nesse sentido a aposta modernista na teatralidade de Piolin parece-me uma escolha feliz. Lúkacs escreveu que a poesia primitiva parte sempre do fato fundamental da importância da práxis. E essa atividade, na sua acepção mais ampla, só existe porque transcende a atuação meramente estética. A teatralidade 
de Piolin não era produzida como "obra de arte”, mas como diversão para consumo, e seu rigor decorre das exigências de eficácia imediata. Sua qualidade artística provinha de uma construção destinada a outros fins, e essa funcionalidade para lá de estética de sua arte, seria central para a discussão da cultura a partir dos anos 1930.

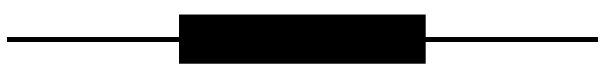

\section{Referências bibliográficas}

ANDRADE, Mário de. Teatro-circo: do Brasil ao Far-West - Piolin. Terra roxa e outras terras, São Paulo, n. 2, 03/02/1926

MACHADO, Alcântara. Indesejáveis. Terra roxa e outras terras, São Paulo, n. 2, 20/01/1926.

Teatro do Brasil. Movimento, Rio de Janeiro, n. 2, nov./1928, apud LARA, Cecília de. De Pirandello a Piolim: Alcântara Machado e o Teatro no Modernismo. Rio de Janeiro: Mincl Inacen, 1987.

SCHWARZ, Roberto. A carroça, o bonde e o poeta modernista. In: Que horas são?. São Paulo: Companhia das Letras, 1989. 